\title{
Allotment gardens in the Lublin downtown in the spatial and urban planning context - origins and issues concerning their preservation
}

\author{
Natalia Przesmycka \\ n.przesmycka@pollub.pl \\ Faculty of Civil Engineering and Architecture, Lublin University of Technology \\ Rafał Strojny \\ rafalstrojny1996@gmail.com \\ Faculty of Civil Engineering and Architecture, Lublin University of Technology
}

\begin{abstract}
Allotment gardens situated in city centers are particularly at risk of the development of buildings serving commercial (service-related or residential) purposes. The present article presents allotment gardens in the downtown of Lublin from the historical, architectural and landscape context. The analysis of urban planning determinants was undertaken for the functioning of gardens from the moment of their establishment until the present day at the example of the oldest of them "Nasza Zdobycz nad Bystrzycą". The article also constitutes an attempt to explain the increasing alienation of the owners of allotment gardens, progressing devastation of the area of allotment gardens as well as to present a suggestion for design application inscribing in the scope of revitalization of this area.
\end{abstract}

Keywords: Allotment gardens, Lublin, revitalization, Rusałka.

\section{Introduction}

Allotment gardens constitute an important element of the landscape of Lublin downtown. Their complex Nasza Zdobycz by the Bystrzyca River - existing since the 1930s in the area of Rusałka Street, together with family allotment gardens established after the Second World War within the Podzamcze district, constitute the background for the panorama of the Old Town Hill and the historic downtown. Both complexes are located in the immediate vicinity of Bystrzyca River and recreational cycling and pedestrian route forming their borders along the river. Wetlands by river valleys were for years considered problematic for undertaking construction activities within them. Current technical opportunities make it possible to shape architectural developments in a practically unrestricted manner, even in view of unfavorable land conditions, which is proved by different projects in the Bystrzyca River valley.

The subject of allotment gardens is very controversial due to the diversified attitudes of the citizens of Lublin and the owners themselves. Some of them perceive the gardens as useless, while others treat them as a very precious element, forming a unique identity of this place. In recent years, the subject of allotment gardens has attracted a lot of attention in connection with the government's attempt to introduce the act on allotment gardens in 2013, posing a threat to the existence of gardens ${ }^{1}$. The act encountered vivid protest and owners' 
"fight" for their gardens. Liquidating a garden may result in losing greenery, which has a large potential on the scale of the city, may lead to the occurrence of disharmony in the existing urban tissue as well as have a negative impact on the aesthetic when the land is sold to developers. The $21^{\text {st }}$ century marks the period of demographic growth, which makes it necessary to satisfy the needs resulting from urban development. Appropriate activities may transform the gardens into flourishing and fully used city greenery, satisfy increasing food demand, motivate social participation and activity. The suggestion for preservation and modifying the basis of functioning of the gardens constitutes an attempt to answer the question whether allotment gardens may become an attractive, partially public space, serve as city farms and contribute to the revitalization of their surroundings, and as a result, be an element on the way to provide adjacent areas with a new urban quality.

\section{Advancement of research and study material}

The field of research refers to the areas of allotment gardens situated in the Lublin downtown, understood as a functional and landscape area. Two garden complexes were examined, located within the viewing foreground of the Old Town panorama, situated on the left bank of the Bystrzyca River within the Rusałka Street and historical Łąki Tatary meadows.

The study was based on the available archive materials - plans originating from the Archives of the Planning Department of the Lublin City Hall, a manuscript chronicle of the "Nasza Zdobycz" allotment garden by the Bystrzyca River ${ }^{2}$, extensive interviews performed with garden owners as well as own records gathered in situ.

In Poland, allotment gardens have a long tradition and they constitute the subject of research within different fields of science (history, urban planning, social issues, spatial development). Already in the inter-war period, allotment gardens were described in subject-related literature and monographs (Kubik 1912, Kosińska 1934, Wilczyński 1927, Lubawy 1939). In subsequent decades, allotment gardens did not constitute the subject of research. As late as in the recent years, we can notice the comeback of scientific publications referring to the topic of allotment gardens, usually in the context of their role in the urban space (Pawlikowska-Piechotka 2010, Szczęsny, Kimic 2012, Szkup, Pytel 2016, Dymek, Bednorz 2017, Szczepańska, Krzyżaniak, Świerk, Urbański 2016, Gawryszewska (ed.) 2015). Social perception of allotment gardens is conditioned to a large extent by their aesthetics and the level of being cared for, which is visible not only in the context of Polish examples (Scott A., Dean A., Barry V., Kotter R., 2018). Allotment gardens undoubtedly contribute to increasing biodiversity in the city as well as have a positive influence on its microclimate (Cabral, et. al. 2017).

Allotment gardens in Lublin were already the subject of research interest of nature scientists and landscape architects who would analyze them in connection with their vegetation and biological role in the ecosystem of the city (Adamiec 2010, a, b). In 1935, the publication by the Association of Gardening Enthusiasts was issued, entitled Lublin Voivodeship and allotment gardens, which to a large extent concerns historical outline and the development of these two gardens. It also describes vegetation diversity on the plots as well as the initiative to do sports within these areas. One can also find there the chapter devoted to solutions which are supposed for the gardens to serve as support for the unemployed of that time. In 1939, Władysław Lubawy includes in his book Historia ogrodów dziatkowych w Polsce (The History of Allotment Gardens in Poland) statistical data presenting an increasing number of allotment gardens within the Lublin Voivodeship. According to the information which can be found there, in 1932, there existed two gardens with a total surface of 8 hectares, while in 1937 the number grew to 80 hectares forming 17 gardens. In 1974, Henryk Gawarecki mentions in his book O dawnym Lublinie (On the History of Lublin) how city greenery was reduced, which resulted in the trend among citizens to maintain continuous contact with nature, made possible by allotment gardens. The author also emphasizes that in the initial period of their functioning the gardens also served the educational function through day camps organized within their premises.

At present, there are 47 allotment gardens in Lublin ${ }^{3}$. Their owners form the group of about 15 thousand members. They take up about 400 hectares. Compared to the city, it constitutes about $3.1 \%$ of the administrative

2 The name of the allotment garden changed - initially the garden was called "Nasza Zdobycz nad Bystrzycą" and currently the name "Nasza Zdobycz" is used.

3 https://www.dziennikwschodni.pl/lublin/400-hektarow-lakomego-kaska-czy-dzialkowcy-moga-spac-spokojnie,n,1000153581.html 
surface of Lublin. Downtown gardens take up about 40 hectares, which constitutes $8.5 \%$ of the administrative surface of the Downtown and Old Town districts ${ }^{4}$.

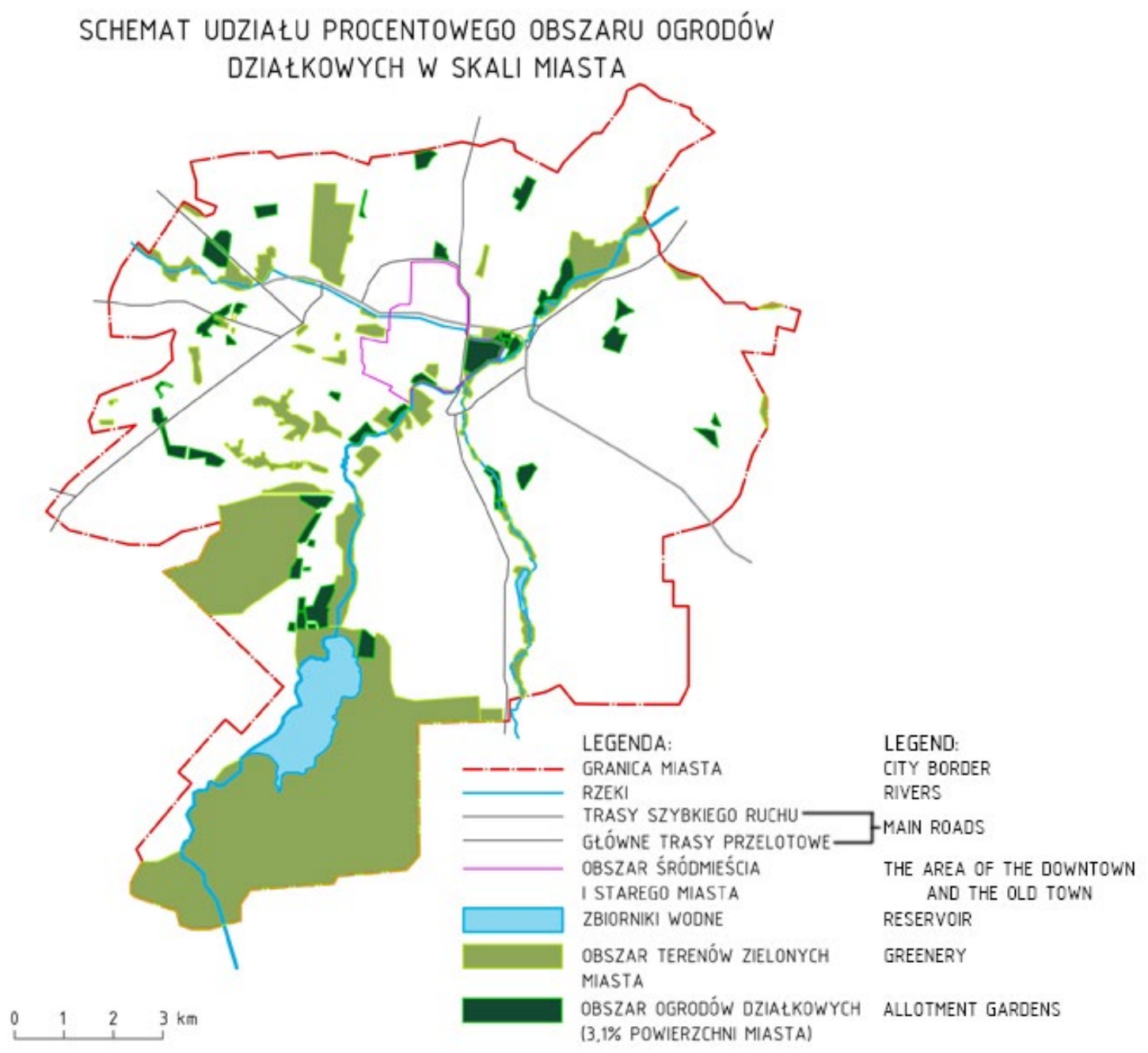

Fig. 1. Distribution of allotment gardens in Lublin compared to green areas. Developed by R. Strojny 2018.

\section{Origins of allotment gardens in Lublin}

Allotment gardens, understood as a form of agricultural activity within the city, used to emerge in Europe in the mature phase of the $19^{\text {th }}$-century industrial revolution, constituting among others the response to the lack of access to fresh food that many workers' families suffered from. The period of economic crises, particularly in the 1930s, contributed to the development of subsequent city gardens. City gardening were developed to a varying extent and under different forms in European countries. Poland belonged to the group of countries in which the development of allotment gardens was connected with the willingness to provide the poorest citizens with food during the industrialization period and as a result of philanthropic thoughts and the development of Ebenezer Howard's idea of garden cities. The allotment garden established by Dr. Jalkowski in Grudziądz 
in 1897 is considered the first facility of this kind in history ${ }^{5}$. According to statistical data, in 1918 in Poland there were 19 gardens with the surface of 70.16 hectares $^{6}$, while in 1937 their number reached as many as 421 gardens, taking up the surface of 2704.68 hectares. After WW2, there were 1500 gardens and their greatest development could be observed in the 1980s, when they began to constitute the surface of 14000 hectares $^{7}$. After 1989 the function of allotment gardens was rather concentrated around recreation than the production of fruits and vegetables. The study from 2011 showed that persons aged 51-65 constitute the biggest group of users of allotment gardens ${ }^{8}$.

International allotment gardens movement emerged in the years 1911-1950, i.e. in the period of two world wars, economic crises and food shortages. First unions, clubs and associations of allotment garden owners were established then ${ }^{9}$. As far as the city of Lublin is concerned, references to the idea of garden housing estates and garden cities were still implemented in the 1930s, the best example of which is constituted by the establishment of the Tenth District under the form of a garden suburb as well as the urban concept of the Ponikwoda district ${ }^{10}$.

Allotment gardens in Lublin were vividly established most often on wet and undeveloped lands in the vicinity of residential areas. These areas were practically deprived of any facilities (no fencing, water supply network or alleys). With the course of time, subsequent plots and common areas were successively developed ${ }^{11}$. The establishment of Lublin allotment gardens coincides in time with the period of great economic crisis (1932-1937) when their organization received the form of support activities for the unemployed. In that time, with the financial support of the Labor Funds, special allotment gardens colonies were established all over the country to serve the unemployed ${ }^{12}$.

\section{History of the establishment of the first allotment garden in Lublin}

The first allotment garden in Lublin was established in 1933. It was called "Nasz Plon"(Our Harvest) and was not preserved until today. The allotment garden "Nasza Zdobycz Nad Bystrzycą" (Our Achievement by the Bystrzyca River) was officially established a year later ${ }^{13}$.

The garden "Nasza Zdobycz"14 was established in 1934 at the initiative of the Association of Gardening Enthusiasts. It was the first garden of this kind within the city of Lublin. The garden was located in the area called Rusałka, formed by meadows partially used for recreational purposes and extending between the Bystrzyca River and Rusałka Street. In connection with the vicinity of buildings forming the downtown as well as good connection with southern part of Lublin, developing from the fourth quarter of the $19^{\text {th }}$ century (Bronowice, Piaski suburb, vicinity of the railway station, district Za Tunelem and the Tenth District), the area of river meadows situated on the western side of the bridge on Zamojska Street was predestined to serve a recreational function. The view from "Rusałka" to the panorama of the city, preserved on Lublin iconography numerous times, constituted another important factor here ${ }^{15}$. In the late $19^{\text {th }}$ century, attempts were made to develop

5 According to the sources, the garden named after the Greater Poland Insurrectionists in Koźmin Wielkopolski established in the $18^{\text {th }}$ century was the first on the territory of Poland. However, the "Kappiele Słoneczne" (Sunbathing) garden in Grudziądz established in 1897 is considered the most similar in its form to current allotment gardens. A history of Urban garden in Europe, Keshavarz N., Bell S., p. 13

6 Władysław Lubawy, Historia ogrodów działkowych w Polsce (History of allotment gardens in Poland), Centralny Związek Towarzystw Ogrodów Działkowych i Osiedli Rzeczypospolitej Polskiej w Warszawie (Central Association of Allotment Gardens and Residential Estates Union of the Republic of Poland in Warsaw), Warszawa 1939, pages 36-38

7 http://pzd.pl/artykuly/12746/108/Rodzinne-ogrody-dzialkowe-w-miastach-dzisiaj-i-jutro---wyzwania-i-funkcje.html

8 Ibidem

9 A history of urban garden in Europe, Keshavarz N., Bell S., p. 8-10.

10 N. Przesmycka, Lublin. Przeobrażenia urbanistyczne 1815-1939 (Lublin. Urban transformations 1815-1939), Publishing House of Lublin University of Technology, Lublin 2012.

11 P. 4

12 Kilka słów o ogródkach działkowych (A few words about allotment gardens), p. 5

13 Association of Gardening Enthusiasts in Lublin, Województwo Lubelskie a ogrody działkowe (Lublin Voivodeship and allotment gardens), Lublin 1935, pages 10-12.

14 Ibidem, p. 13. The name used alternately with "Nasza Zdobycz nad Bystrzycą", Garden Chronicle includes the information about 1932 as the establishment date.

15 The oldest representation of the city from this point of view is the engraving from the work by Barun and Hogenberg....., Hackert, etc. The area was frequently represented on postcards. 
this area in order to serve a recreational and cultural function. The building of timber "on-the-water" theater was constructed in 1898 , together with canoe harbors and bathing zones. The projects described above were undertaken in the eastern part of "Rusałka", while the western zone was not developed to such an extent. It included meadows as well as constituted an illegal landfill ${ }^{16}$.

a

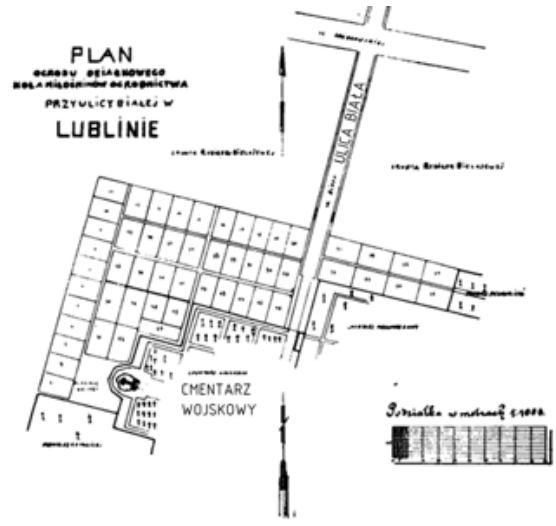

b

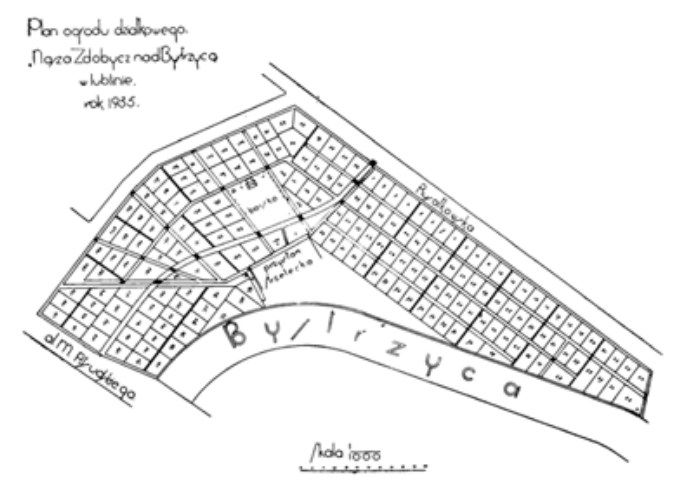

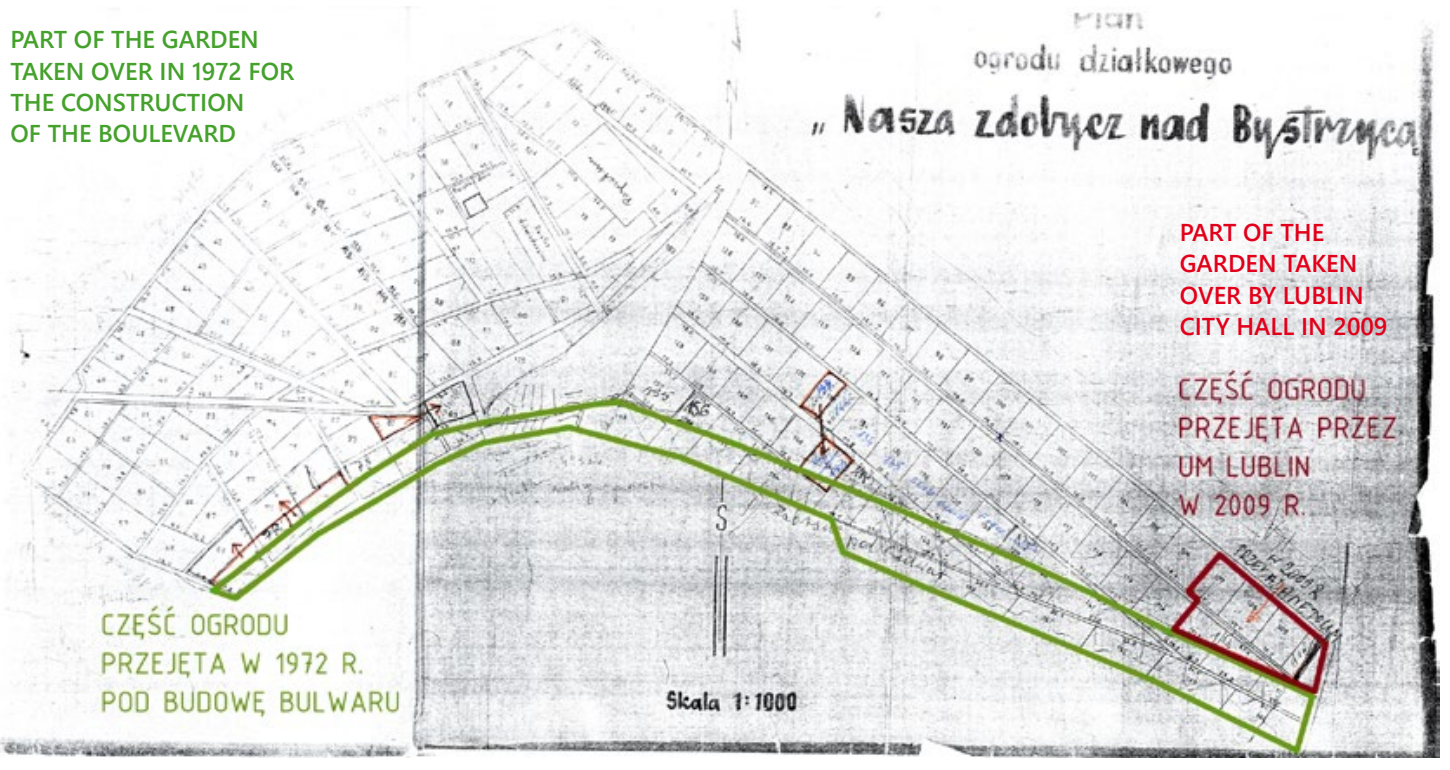

Fig. 2. A, B - plans of the oldest allotment gardens in Lublin, Source: Association of Gardening Enthusiasts in Lublin, Województwo Lubelskie a ogrody dziatkowe (Lublin Voivodeship and allotment gardens), Lublin 1935, C - ownership structure of the "Nasza Zdobycz" garden after subsequent annexations, developed by R. Strojny 2018

The Association of Gardening Enthusiast was established on April $27^{\text {th }} 1932^{17}$. The main objective of the association consisted of the activities aimed at improving health and the aesthetic qualities of the city. Initially, association's activities included: conducting the courses devoted to caring for house plants, decorating balconies and residential buildings as well as organizing gardening competitions. In the autumn of 1932, an attempt was made to obtain areas for the official establishment of the allotment garden from the city ${ }^{18}$. The intention was to locate the garden at a short distance from the place of residence of its future users, make it easily accessible

16 Chronicle of the garden "Nasza zdobycz nad Bystrzycą", M. Kozyra, written in the late 1980s basing on the collected archival, press and photographic materials of the garden management.

17 Association of Gardening Enthusiasts in Lublin, Województwo Lubelskie a ogrody działkowe (Lublin Voivodeship and Allotment Gardens), Lublin 1935, p. 10. Another source quotes the date of May $27^{\text {th }} 1931$ - M. Kozyra, Chronicle of the garden "Nasza zdobycz nad Bystrzycą", manuscript owned by the management of the "Nasza Zdobycz" Allotment Garden in Lublin.

18 Ibidem, p. 10 
and characterized by good quality soil. On November $17^{\text {th }} 1932$, during the meeting with the representatives of different authorities called by the Association of Gardening Enthusiasts K. Jankowski, Director of Public Works, informed about the chance which had emerged for the lease of city spaces for the establishment of allotment gardens. On March $30^{\text {th }} 1933$, a lease agreement was signed with State Treasury. The area assigned to the association members consisted of 2 hectares of the "Nasz Plon" allotment garden, together with 6 hectares of the "Nasza Zdobycz" garden. In the spring of 1933, the first gardeners began their activity. The participants of the initiating general meeting accepted "Nasza Zdobycz nad Bystrzycą" as the name for the garden"19.

Early days of the existence of the garden turned out to be difficult, as the land was not meliorated, and before, it had constituted a landfill. There was no fencing or gazebos, and water was taken from the river. On June $10^{\text {th }} 1934$, the "Gardens Festival" was organized. The ceremony began with a march on the streets of Lublin and reached the "Nasza Zdobycz" allotment garden. The march was led by children holding banners with the following slogans: "Long live allotment gardens", "Allotment gardens bring health to citizens", "There is no Lublin without the gardens", "We love the gardens" etc. The banners were ornamented with such radish, kohlrabi etc. At the end of the parade, a children's ball was held. The day of the "Gardens Festival" was summarized with the general meeting of gardeners, during which the activity of the Association of Gardening Enthusiasts was extended into other cities: Zamość, Chełm and Siedlce. In late 1934, the Association was transformed into the Society of Allotment Gardens and Residential Estates. In the interwar period, the garden served a very important educational function - day camps for children were organized there. A playground was constructed together with a shooting range ${ }^{20}$. In the years 1934-1949, the area of the garden was organized and fenced, wells were constructed together with the pavilion which became the seat of the management's office. In 1949, the gardens were taken over by the Central Trade Unions Council ${ }^{21}$.

\section{Development and functioning of the garden}

In 1939, the garden was overgrown with very little trees and bushes. Before, only a few gardeners had their own gazebos, and those which existed there rather resembled storage sheds.

After the end of the war, the construction of gazebos was not controlled by the Management of the Garden, which resulted in the fact that they would often take various forms, while their look would leave a lot to be desired. However, this issue was regulated with time and gazebo types were developed. Before the construction of a gazebo, its owner had to present the design for acceptance by the Management of the Garden and receive permission ${ }^{22}$. New decorative bushes and dwarf trees were planted from year to year. Gardens began to change their character from those intended for the cultivation of vegetables into decorative and recreational ones, maintaining the function of vegetable and fruit production.

"Experimental Circle" was established in 1950 by Krystyna Jastrzębska, uniting 20 members. On the surface of $1100 \mathrm{~m}^{2}$, it had 38 cold frames, in which the seedlings of tomatoes, peppers and lettuce were cultivated. Other were used for the most beautiful species of bulb flowers, such as tulips, gladioluses, daffodils, crocuses. The plantation of roses, as well as dwarf fruit trees, were also established. The circle used to satisfy the needs of gardeners and excess products were intended for sale. In 1969, its activity was extended with bee breeding. Plot owners represented among others by railwaymen, militia members, the employees of the post office, education sector, national councils as well as commerce. Gardeners aged 40-60 prevailed. On average, from 2 to 5 gardens would change their owners every year ${ }^{23}$.

In 1950, the gardeners received the adjacent area on the opposite side of Rusałka Street. One hundred and nine plots were arranged there, in this way increasing the number of plots in the entire garden to 278 . In the

19 M. Kozyra, Chronicle of the garden "Nasza zdobycz nad Bystrzycą", manuscript owned by the management of the "Nasza Zdobycz" Allotment Garden in Lublin.

20 Henryk Gawarecki, O dawnym Lublinie, szkice z przeszłości miasta (On the History of Lublin, sketches on the city in the past), Wydawnictwo Lubelskie, Lublin 1974, p. 218

21 M. Kozyra, Chronicle of the garden "Nasza zdobycz nad Bystrzycą", manuscript owned by the Management of "Nasza Zdobycz" Allotment Garden in Lublin.

22 At present the gazebo can have the maximum surface of $35 \mathrm{~m} 2$, which results directly from the Construction Law in force.

23 M. Kozyra, Kronika ogrodu..., op. cit. 
older section of the garden, the surface of plots amounted to $200-300 \mathrm{~m}^{2}$ and in the new part having a temporary location $-400 \mathrm{~m}^{2}$. The surface for agricultural purposes amounted to 9 hectares, while 2 hectares were formed by squares, green areas, roads and fallow lands. In 1957, allotment plots took up the space of 109.1 hectares of the entire city, which gives $7.8 \mathrm{~m}^{2}$ of allotment gardens per capita per citizen ${ }^{24}$. Due to the rapidly growing number of citizens, three years later this ratio decreased to $6.8 \mathrm{~m}^{2}$ (122.9 hectares of gardens, which constituted the area compliant with the normative standard of that time $)^{25}$.

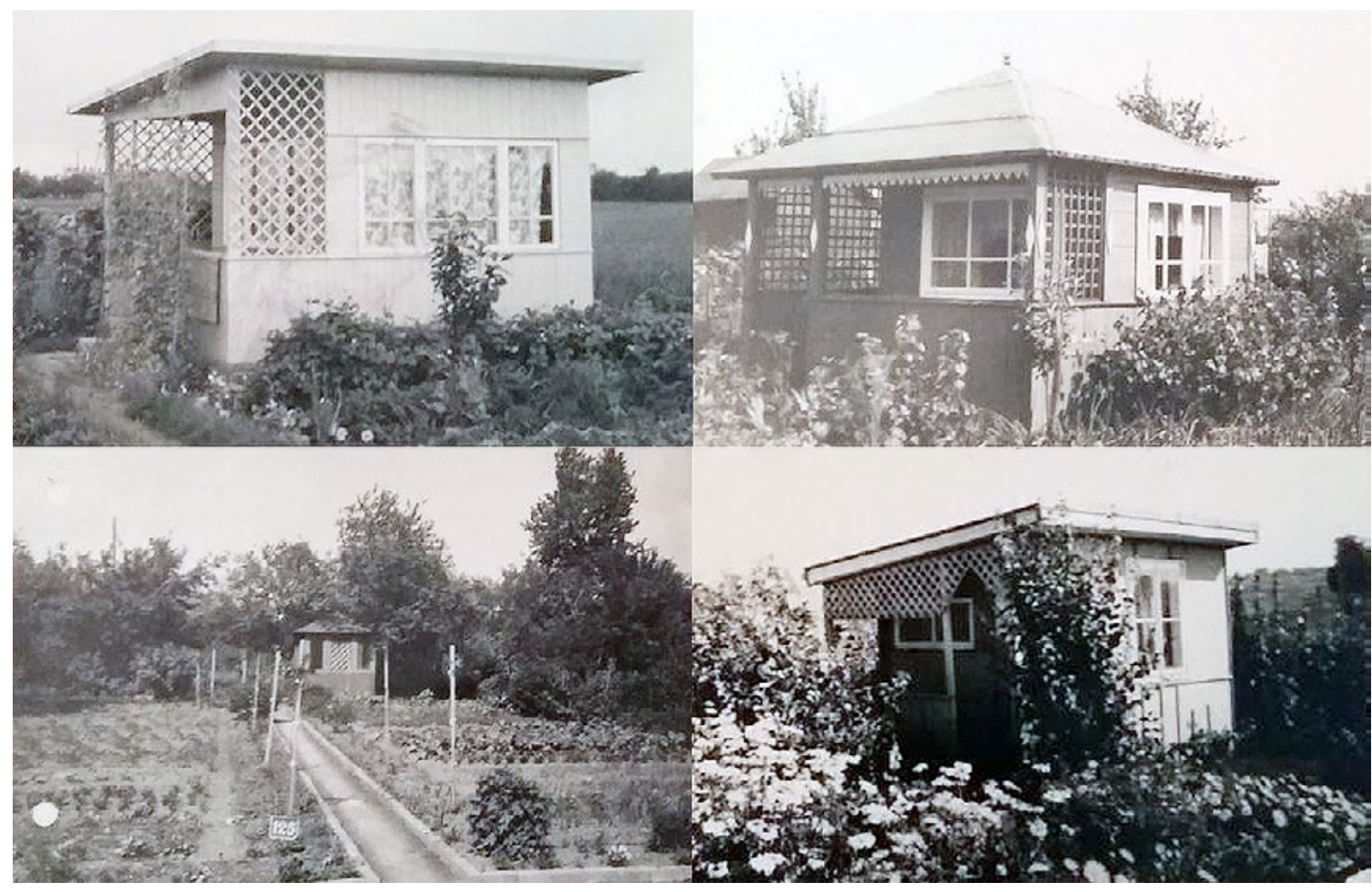

Fig. 3. Archival photographs of gazebos on allotment gardens, source: Chronicle of the garden "Nasza zdobycz nad Bystrzycą", M. Kozyra, written in the late 1980s basing on the collected archival, press and photographic materials of the garden management.

In the years 1950-1969, further development of the garden took place. Also, thanks to the subsidy, a new timber pavilion was constructed in the central part of the garden, which included the Board's chancellery, library, Women's Commission room, assembly hall for 250 participants. On September $3^{\text {rd }} 1952$, the official commissioning of the pavilion took place. A sewage network was developed in the older section of the garden and 81 taps were assembled. The garden obtained new fencing, steps were constructed in the main alley and all aisles were separated with curbs. Apart from material input and expert's advice, all works were performed voluntarily by the gardeners. In addition to the administration pavilion, the garden includes also a storage pavilion for the equipment necessary for plant cultivation. Brick and mortar sanitary devices were also performed.

In the 1970s, the modernization of the area was conducted. The aisles were widened and separated with curbs, draining trenches were equipped with concrete culverts. Flowerbeds were established, planted with roses and entrance gates were decorated with clematises. From 1952, the timber pavilion from was thermally insulated with aerated concrete, while office rooms were painted. New fencing from the Rusałka Street was also constructed. In 1986, the performed tree records reported the existence of a lot of various species of fruit trees and bushes as well as vegetables. The garden was the first to include the plantations of such vegetables 
as scorzonera, eggplant, bok choy, endive, broccoli, etc., which were uncommon at that time. The average yield of a plot reached $600 \mathrm{~kg}$ of vegetables, fruits excluded ${ }^{26}$.

The social and cultural activity of gardeners was equally rich. Already in 1946, a community room was opened for teenagers (not only those belonging to plot owners' families). Day camps for children were organized every year, together with meetings, gatherings and parties on the occasion of Gardener's Day, Mother's Day, Children's Day, national holidays etc. Such events are also held now, and additionally, pupils from nearby schools visit the garden within the framework of their Biology classes.

In 1975, the exhibition of flowers and crops began to be organized on the occasion of the Harvest Festival in the renovated timber pavilion. In 1976, a delegation of gardeners from the Czech Republic, Slovakia and German Democratic Republic visited the "Nasza Zdobycz" garden in order to share their experience connected with the functioning of this type of gardens. For years, the garden has won numerous distinctions and diplomas ${ }^{27}$.

\section{First threats for the functioning of the garden}

The surface of the allotment garden within the so-called Rusałka area, due to its attractive location in the Lublin downtown, was included in planning works conducted by the Lublin Urban Planning Atelier ${ }^{28}$. In 1957, the establishment of the Downtown Park with the surface of ca. 10 hectares was planned within this area, taking up the space of former meadows on both sides of Rusałka Street, through liquidating the allotment gardens ${ }^{29}$. The park was supposed to pass the bridge at Zamojska Street and connect with the Culture Park with the surface of 90 hectares taking up the area of wet meadows within the former Royal Pond in the Podzamcze district. The General Plan from 1969 followed previous assumptions referring to establishing a park on Rusałka grounds. In 1960, allotment gardens within the Downtown took up the surface of 43.9 hectares (the largest among Lublin districts $)^{30}$. The plan from 1969 assumed preserving the western part of allotment gardens in the vicinity of the designed park area ${ }^{31}$. In the same year, the design for the reorganization of the arrangement of allotment gardens in the entire city of Lublin was developed. Gardens located within the valley of the Bystrzyca River: in Podzamcze, Rusałka, within the former Krause's mill in Tatary district on the right bank of Czerniejówka River were intended for liquidation. Allotment gardens supposed to replace them were designed on the outskirts of the city or arable lands. Nasza Zdobycz Allotment Garden was supposed to be liquidated in the years 1973-75, while the garden in Podzamcze in the years 1976-1980 32 .

Already in 1972, the city took over 68 plots for the construction of the boulevard and the liquidation of the newest part of the garden on the northern side of Rusałka Street took place. As a part of the compromise, gardeners received 6.5 hectares of meadow at Wapienna Street and in the spring of 1973 moved it to new areas.

However, the construction of a park on the Rusałka grounds did not become a fact, even if subsequent detailed urban planning designs were developed (similarly for the park in the Podzamcze district). Uncertainty referring to the existence of allotment gardens has accompanied their users since 1970s.

26 M. Kozyra, Chronicle of the garden "Nasza zdobycz nad Bystrzycą", manuscript owned by the management of the "Nasza Zdobycz" Allotment Garden in Lublin.

27 Among others: diploma for the organization of fairs, exhibition of crops and flowers, diploma for engagement in environmental protection diploma for the development of workers' allotment gardens, for the organization of summer stays for pensioners. M. Kozyra, Chronicle of the garden "Nasza zdobycz nad Bystrzycą", manuscript owned by the management of the "Nasza Zdobycz" Allotment Garden in Lublin.

28 In the General Plan of the City of Lublin from 1954, the area was intended for boulevards, promenades and green areas - allotment gardens were planned exclusively in the area of Wapienna Street. Lublin, General Spatial Development Scheme, Miastoprojekt Wschód - Design enterprise, Eng. Kaszycki, Eng. Wilski, together with the description to the plan 1957, p. C-58 Urban Planning Atelier M.Z.A.B. in Lublin, 1957, typescript.

29 lbid.

30 General Spatial Development Scheme. Perspective 1969.

31 Ibid.

32 The city of Lublin. Allotment gardens. Records. 1969, 1:1000 plan. 

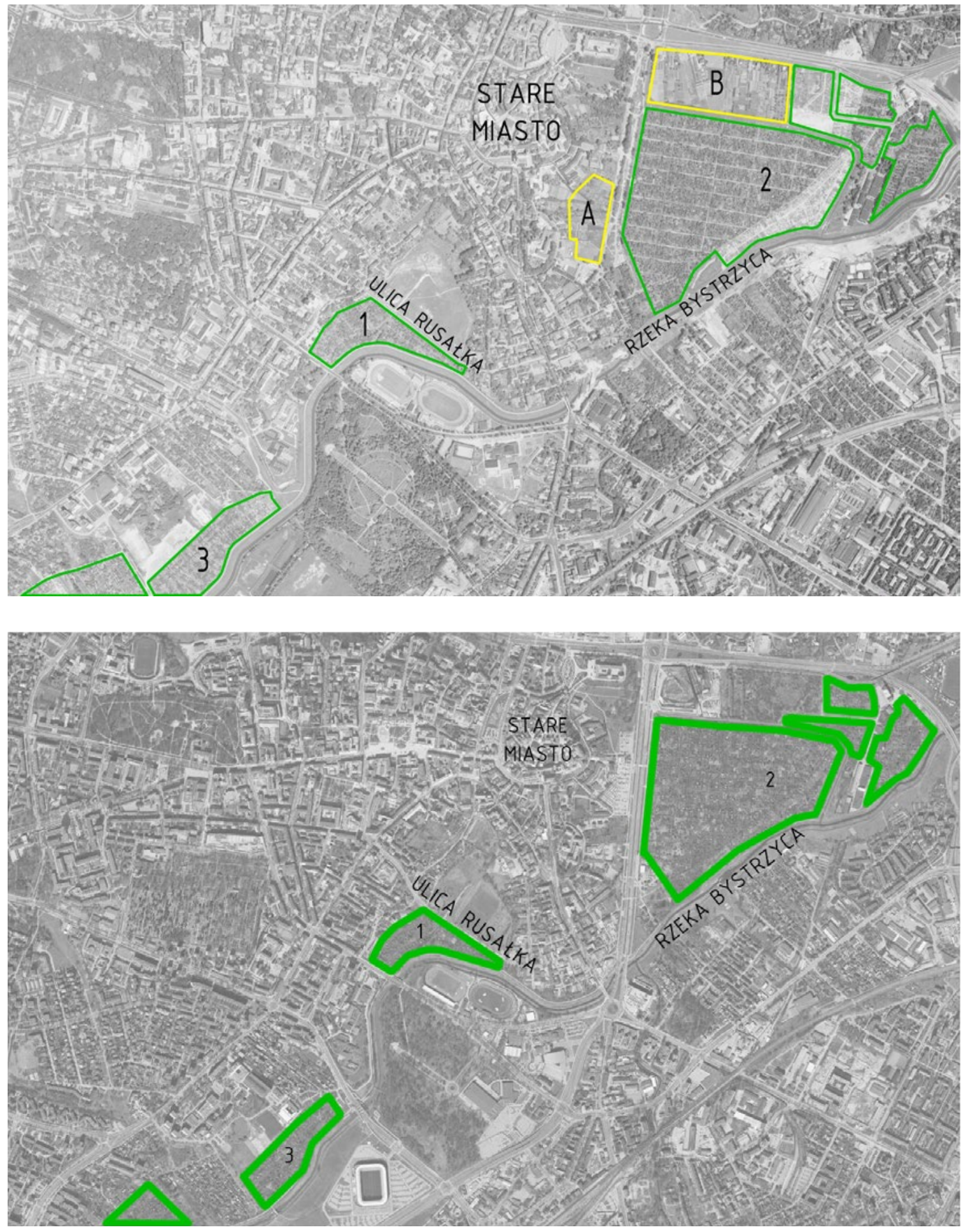

Fig. 4, 5. View as of 1980s together with current state. 1 - Family Allotment Garden "Nasza Zdobycz" at Rusałka Street, 2 Workers Allotment Garden "Podzamcze" within the area of Łąki Tatary and Podzamcze districts, 3 - Family Allotment Garden "Bystrzyca". A, B - agricultural grounds within the downtown zone. Developed by R. Strojny 2018. 

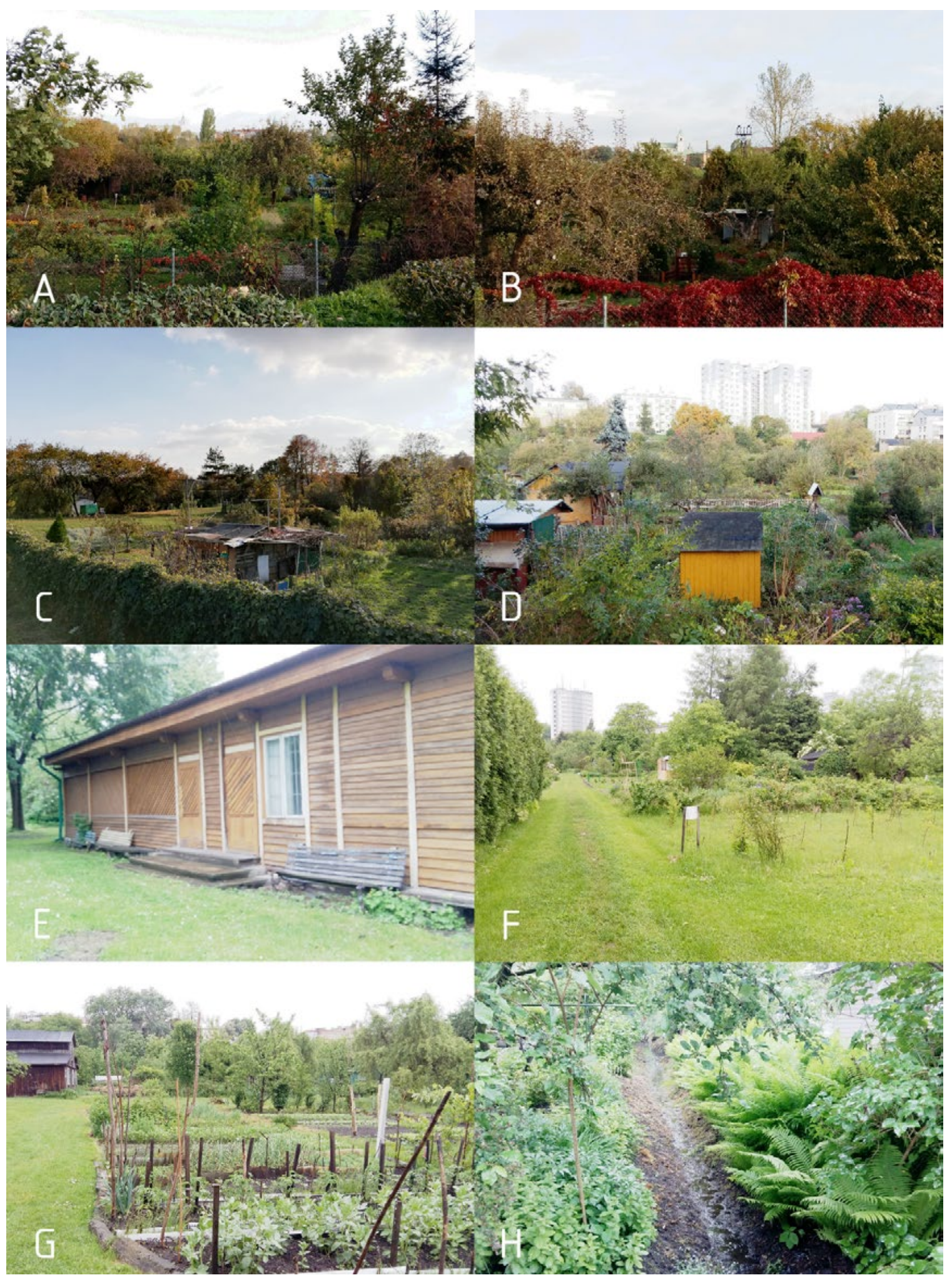

Fig. 6. Fig. 6. A, B - view from the side of the walking and bicycle path on the boulevard of the Bystrzyca River towards the Old Town, C - view in the direction of the river from Rusałka Street, D - view from the boulevard to Dolna Panny Marii Street, E - timber multi-functional pavilion, erected in 1952, F, G - view of the central part of the garden, $\mathrm{H}$ - one of rain watercourses. Photo R. Strojny 2017/2018 


\section{Allotment gardens in the Lublin downtown - current state}

The opinion of the society referring to the owners of allotment gardens is currently very diversified and a lot of inhabitants of the city have never had any contact with allotment gardens. Part of the society perceives the owners of allotment gardens as a group forming their own closed community. In order to deepen the knowledge about the area, an interview was conducted with Teresa Wrońska, the Head of "Nasza Zdobycz" allotment garden ${ }^{33}$. After entering the area of the garden and trying to gather the information about it, one of the gardeners asked: "Are they again trying to take our gardens?". For a person not involved in this matter such attitude may seem incomprehensible, but after interviewing the oldest gardeners and analyzing the history of the garden their attitude may seem justified.

The allotment garden "Nasza Zdobycz" by the Bystrzyca River still looks unique and shows to its visitors how big the treasure owned by the gardeners is. From the outside, it looks neglected and uninteresting, but having entered it one can notice a totally different character of the space. It is true that gazebos and buildings belonging to the management are not in a perfect condition, aisles also require new pavement, but the diversity and richness of greenery are amazing. Plots belonging to subsequent users are not fenced, but separated with curbs, watercourses draining the rainwater resemble rain gardens as they are not usual ditches, but they are in a large part overgrown with plants and aisles extend along them. A lot of plots have pergolas with flowers and evenly cut grass, where daisies or ears of grain appear from time to time. While entering the garden area, you can immediately feel the sense of community between plot users. We can see how they respect and care for their land. Some gardeners breed hens, pigeons or rabbits there.

During the conversations with gardeners, it was possible to feel a very strong sense of belonging to this area as well as notice the pride that they expressed while talking about the oldest allotment garden in Lublin; in spite of so many problems they managed to survive. Disappointment could be heard in their voice when they were describing how they had to go through all these difficulties and fight for what they had already achieved years before. They devoted an important part of their lives for the garden to be perfect. When they compromised and managed to preserve at least the oldest part of the garden, the authorities liquidated the garden on the opposite side and it turned out with time that no funds were available for establishing the Youth Park or the footbridge. As a result, vast green area emerged, including only neglected football pitches with rusty fencing and streetlamps dominating the place. Park area planned for several decades did not serve its function. Growing illegal parking zones, neglected greenery and remnants of recreational infrastructure under the form for example of a sledding hill intensify the impression of an abandoned space. Walking down the Rusałka Street, one can only sometimes see children playing on the sledding hill and the remaining part of this area seems extinct. It is particularly difficult for the gardeners to see the condition in which the areas which used to constitute their property and could remain vibrant currently are.

The areas of allotment gardens within the former Łąki Tatary and Podzamcze districts were also reduced in the course of time, which was connected with municipal and commercial investment projects. Planned realization of the park together with recreational areas did not succeed, but recreational infrastructure is growing on the right banks of the Bystrzyca River, connected with the bicycle path along the river. The river itself is here more accessible to anglers and canoeists.

\section{Gardens and their future - liquidation or preservation?}

Allotment gardens in city centers, also in Lublin, have constituted a contentious issue for years. Liquidating the garden may result in losing green areas representing important potential on the scale of the entire city, contribute to disharmonies in the existing urban tissue as well as decrease the aesthetics and natural value of the place if the land is sold to developers and intended for commercial or residential purposes.

The greatest space-related issue connected not with the presence itself of allotment gardens in the Lublin downtown, but rather with their isolation and limited access, is constituted by closing the areas by the river, functioning as publicly available recreational grounds, from the downtown zone. 
Current urban planning trends referring to the protection of green areas in central zones of the cities seem to promote the preservation of allotment gardens in the Lublin downtown. In highly developed countries new forms of city greenery and urban farming become popular, both under their industrialized as well as spontaneous forms. We can differentiate here social and neighbors' gardens, guerilla gardening together with various forms of urban gardening concentrated on obtaining valuable, healthy and natural food. Interestingly enough, in poorer countries, where informal urban farming constitutes the answer to food shortages, social perception of these areas is more negative, and they are usually located in the peripheries (Schwab, Caputo, Hernandez-Garcie, 2018).

The Rusałka area is subject to municipal Revitalization program. It assumes the reconstruction of Rusałka Park together with a skatepark, which will constitute one of the places activating the citizens, local entrepreneurs as well as attracting visitors from other districts and tourists. Buildings representing bad technical condition are going to be liquidated and the remaining part of the existing development is going to be renovated. The area by Rusałka Street was considered to constitute the greatest potential in developing new green areas ${ }^{34}$.

In the revitalization and development concept program prepared in 2017 for the valley of the Bystrzyca River in Lublin within the area of allotment gardens in the Downtown, the establishment of park zones was planned. The presence of the function of urban gardening was not addressed, while allotment gardens were assessed as elements impeding the development, which "should be transformed into open recreation grounds and within the intermediary phase - perforated, forming open pedestrian and courses of transit character ${ }^{\prime \prime 35}$. The concept returned to the idea of establishing the Rusałka park, completely eliminating the function of allotment gardens. A sensual garden was supposed to be established in their place ${ }^{36}$.

\section{Possibilities for using the potential of allotment gardens in the Lublin downtown in the context of urban agriculture}

Allotment gardens functioning in the Lublin downtown may be considered to form modern city farms, the popularity of which is growing in highly developed countries. Different forms of agricultural activity were present in the cities and towns for centuries (for example monastic gardens). City farms constitute a type of social garden which serves not only the purposes of food production, but also educational and recreational functions. It is a modern multi-functional urban space, resulting from a carefully thought-out and conscious decision of space managers. The farm creates an attractive urban space. In Paris, such areas are present in almost all districts. They form a meeting place for people representing different environments and age groups. Similar solutions can be found in New York and Vienna. England is one of the countries characterized by the greatest advancement referring to the aspect of agriculture.

Urban agriculture consists not only of the areas serving recreation purposes, but also concentrated on sustainable development and food production (the Netherlands, Chile). In some countries, urban farming supplies the cities with as much as $90 \%$ of food (e.g. China) ${ }^{37}$.

The studies of complex urban and social determinants were the motivation for developing the subject of alternative suggestion for the revitalization of the Rusałka area, applying the ideas connected with urban agriculture ${ }^{38}$.

34 Resolution number 735/XXIX/2017 as of April $27^{\text {th }} 2017$ of the Council of the City of Lublin concerning the Revitalization Plan for Lublin in the years 2017-2023

35 Concept, p. 14

36 The Concept assumes intensive use of both the northern as well as southern part of the future park with simultaneous respect for recommendations included in the local plan. It is suggested to connect both parts of the area intended for the park with a footbridge constructed with $5 \%$ downslope to the place where sledding hill is currently situated - but from the height of 7.0 meters - over Rusałka Street, above the area of allotment gardens to the Bystrzyca River bank. In the future, in the place currently taken up by the crops, it is suggested to develop the southern part of "Rusałka" park, intended for a sensual garden.

37 I. Karczmarczyk, Zielone dachy, farmy miejskie i ogrody wertykalne jako element ekologicznego zagospodarowania przestrzeni miejskiej (Green roofs, urban farms and vertical garden as an element of ecological arrangement of urban space), in: Miasto zielone z natury. Poradnik dobrych praktyk. (City green in its nature Guide to good practice.) Szczecin 2014, p. 23.

38 Title of the paper.... 250 surveys were conducted within the framework of the study ... 
DO YOU THINK THAT THE SPACE OF ALLOTMENT GARDENS SHOULD (IN WHOLE OR IN PART) BE ACCESSIBLE TO EVERYONE?

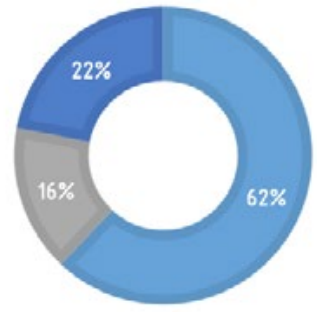

- YES

NO

- NO OPINION

WHAT IS YOUR OPINION ABOUT GREENERY PRESENT WITHIN THIS SPACE?

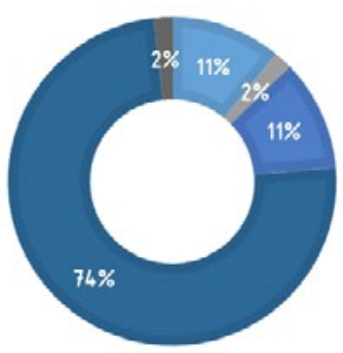

- ENOUGH

IT REQUIRES BETTER

- ARRANGEMENT

IT IS IN GOOD

- CONDITION

- NO OPINION
DO YOU THINK THAT THIS AREA IS ATTRACTIVE FROM THE PERSPECTIVE OF THE CITY?

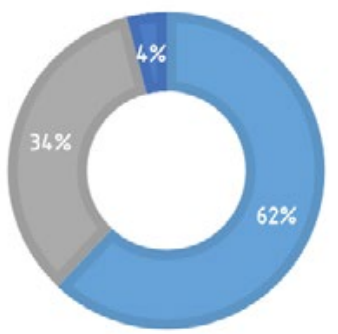

- YES

nO

- NO OPINION

DO YOU LIKE THIS PART OF THE CITY OF LUBLIN?

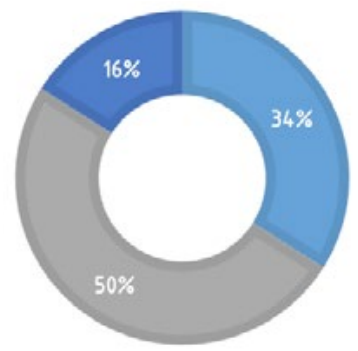

Two hundred and fifty respondents - Lublin citizens - took part in the survey. Among a number of questions asked, a few of them were directly connected with the issue of the functioning of allotment gardens. The majority of respondents (62\%) noticed its big potential on the scale of the city, at the same time perceiving it as unattractive in its current form ( $50 \%$ answered that they do not like the space and $16 \%$ had no opinion about it). The greenery present within the Rusałka zone was assessed by the majority of those surveyed as requiring better arrangement. Sixty-two percent of respondents approved the suggestion for making part of the space of "Nasza Zdobycz" allotment garden by the Bystrzyca River publicly accessible. Results of the survey confirmed social openness to the suggestions of introducing the function of an urban farm, at the same time preserving part of the allotment garden with the framework of Rusałka revitalization project.

The design concept assumes the establishment of an urban park on the northern side of Rusałka Street with introducing new functions (Youth Park, sensual garden, rainwater garden, flower meadows etc.) and connecting the existing recreational boulevard along the Bystrzyca River with communication route conducted in the area of allotment gardens made partially available to the public. The course and form of the main promenade were conditioned by the analysis of landscape and communication connections together with the structure of the internal division of the garden. It was suggested to introduce public space, which constitutes an intermediary structure between private gardens and the recreational zone and the majority of its surface was intended for the organization of modern urban farm. In connection with the location in the heart of the Lublin downtown, part of this space should serve educational functions.

It would constitute publicly available space including various crops, spaces for recreation and integration with nature. Such a zone would integrate the garden with the remaining part of the city as well as open the space to new users. It would initiate social participation and activity in the gardens. At present, gardens constitute fenced space unavailable from the outside. After their transformation, the division into farming lands intended for subsequent gardens would still exist, but they would be integrated with the farm and periodically accessible to everybody. Appropriate plant species could be planted along watercourses in order to filter rainwater from communication pollution, and most importantly, they would make this typical garden structure more attractive. Aisles or promenades could be established along them, from which everyone could admire the crops and remain in contact with nature. Such space would stimulate all senses in the same way as sensual gardens, preserving, at the same time, its usable character. Beds that include cultivated crops could be found by the aisles. 


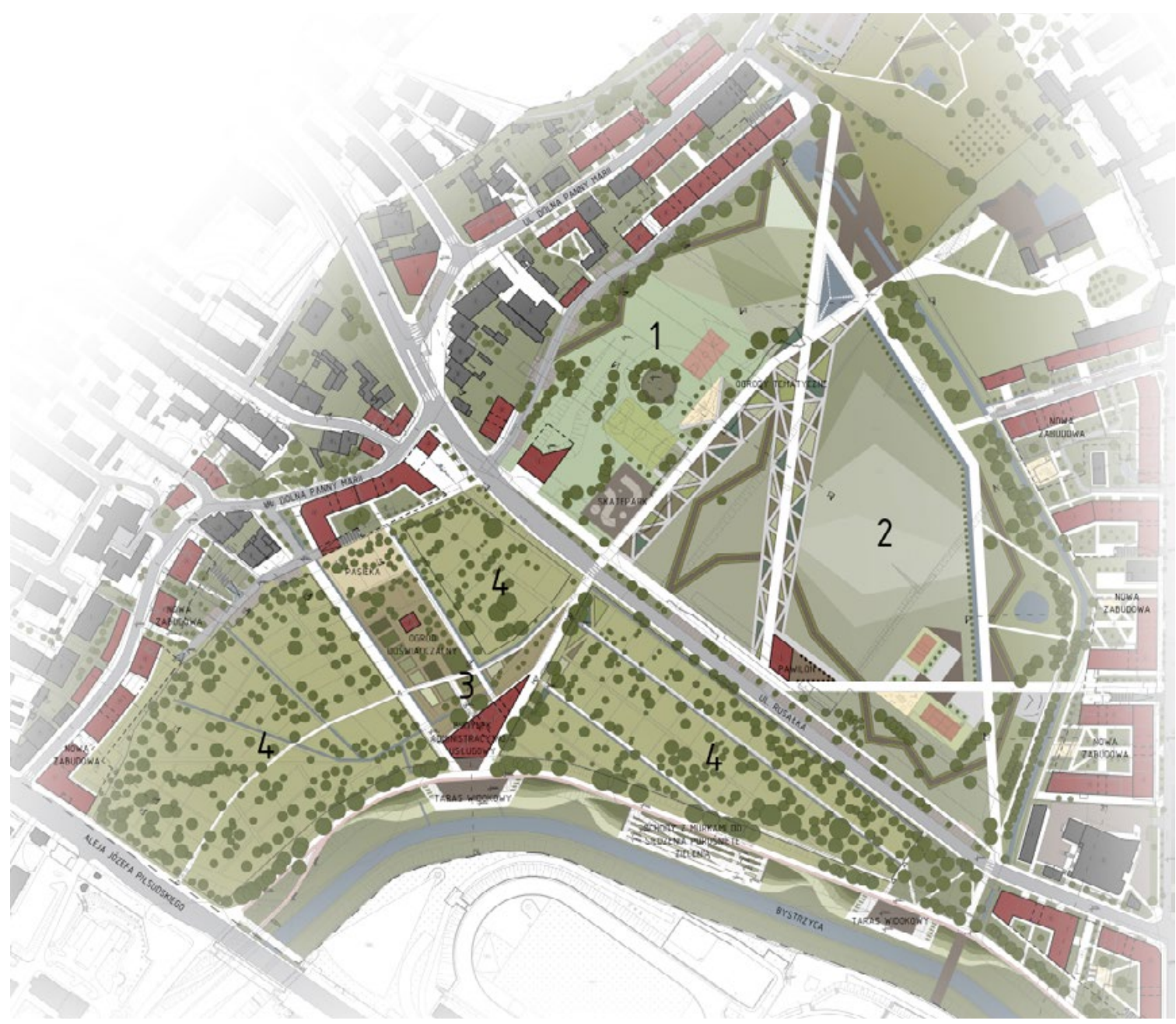

Fig. 7. Urban concept for developing the Rusałka area. 1 - Youth Park, 2 - Rusałka Park, 3 - part of the garden made publicly available in the form of urban farm, 4 - semi-private section of the allotment garden. Source: R. Strojny, Rewitalizacja urbanistyczno-architektoniczna zdegradowanych obszarów miejskich w rejonie ulic: Dolnej Panny Marii, Rusatka, Wesotej oraz rzeki Bystrzycy w Lublinie (Urban and architectural revitalization of degraded urban areas within the Streets: Dolna Panny Marii, Rusałka, Wesoła as well as the Bystrzyca River in Lublin), 2018, engineer thesis under the direction of N. Przesmycka

Even if the idea to introduce an urban farm in the allotment garden by Rusałka in Lublin refers to current trends present in big cities, its aim would not be to copy foreign models, but it would constitute the answer to the needs and realization opportunities. Modernization of allotment gardens will prevent their further degradation, at the same time preserving their historical identity.

\section{Summary}

Allotment gardens located in the Lublin downtown constitute a natural, cultural and social resource developed by several generations of gardeners. The different condition of gazebos and gardens, and in particular no possibility to pass through their area for those who do not form part of the gardeners' community, contribute to negative opinions in this field as well as complex determinants of such a state of affairs. We can hope here that current urban trends promoting urban farming under different forms contribute to the possibility of preserving this already historical function in the space of the Lublin downtown.

Urban planning recommendations constitute the only guarantee for their protection. The chance for opening the city into the river and integrating gardeners with the city may be constituted by making the garden 
publicly available in its part. The revitalization of plots together with their surroundings may help the citizens to find a way of achieving a healthy, sustainable and happy life. The garden may be given the modern function of an urban farm. The farms will eliminate the necessity to transport food and will make it possible to obtain higher quality products. The integration of the urban tissue with gardens in the functional and spatial sense is necessary for the correct course of the process of revitalization of this space. The suggested modifications of the process will restore past glam of the gardens, make it possible to preserve their identity, at the same time making them modern and transforming them to match the needs of the present and future society.

\section{References}

[1] Adamiec P., 2010, Zieleń ogródków działkowych. Wybrane przykłady z Lublina. Rośliny do zadań specjalnych (Greenery of allotment gardens. Chosen examples from Lublin. Plants for special purposes). Ed. M.E. Drozdek Oficyna Wydawnicza PWSZ w Sulechowie. Kalsk Sulechów

[2] Adamiec P., 2010. Zieleń i forma. Zieleń ogródków działkowych. (Greenery and structure. The greenery of allotment gardens)

[3] Cabral I., Keim J., Engelmann R, Kraemer R, Siebert J, Bonn A, Ecosystem services of allotment and community gardens: A Leipzig, Germany case study, Urban Forestry and Urban Greening 23 (4): 44-53

[4] Dymek, Bednorz 2017, Zagospodarowanie Rodzinnych Ogrodów Działkowych (ROD) na przykładzie ROD im. Józefa Chociszewskiego w Poznaniu (Arrangement of Family Allotment Gardens (ROD) at the example of Józef Cichoszewski's ROD in Poznań), Studia Miejskie (Urban Studies) 2017 / 25 | 133-147

[5] Gawarecki H., O dawnym Lublinie, szkice z przeszłości miasta (On the History of Lublin, sketches on the city in the past), Wydawnictwo Lubelskie, Lublin 1974

[6] https://www.dziennikwschodni.pl/lublin/400-hektarow-lakomego-kaska-czy-dzialkowcy-moga-spac-spokojnie,n, 1000153581.html, access on December $2^{\text {nd }} 2018$

[7] Karczmarczyk, Zielone dachy, farmy miejskie i ogrody wertykalne jako element ekologicznego zagospodarowania przestrzeni miejskiej (Green roofs, urban farms and vertical garden as an element of ecological arrangement of urban space), in: Miasto zielone z natury. Poradnik dobrych praktyk. (City green in its nature Guide to good practice). Szczecin 2014, p. 8-37,

[8] Kilka słów o ogródkach działkowych (A few words about allotment gardens), Regional Society of the Associations of Allotment Gardens, Warszawa 1937.

[9] Kosińska J., Lwowskie ogrody działkowe (Lviv allotment gardens), Associaton of Allotment Gardens in Lviv, Lviv 1934.

[10] Kozyra M., Chronicle of the garden "Nasza zdobycz nad Bystrzycą", M. Kozyra, written in the late 1980s basing on the collected archival, press and photographic materials of the garden management, manuscript

[11] Kubik W., Worker's garden (lecture abstract), author's self-funded publication, Lviv 1912.

[12] Lubawy W., Historia ogrodów działkowych w Polsce (History of allotment gardens in Poland), Central Association of Allotment Gardens and Residential Estates Union of the Republic of Poland in Warsaw, Warszawa 1939.

[13] Lubawy W., Historia ogrodów działkowych w Polsce (History of allotment gardens in Poland), Central Association of Allotment Gardens and Residential Estates Union of the Republic of Poland in Warsaw, Warszawa 1939.

[14] General Spatial Development Scheme of the city of Lublin 1957, Miastoprojekt Wschód - Design enterprise, Eng. Kaszycki, Eng. Wilski, together with the description to the plan 1957, p. C-58 Urban Planning Atelier M.Z.A.B. in Lublin, 1957, typescript.

[15] Ogród za oknem. Przyszłość ogrodów działkowych w miastach (Garden by the window. The future of allotment gardens in the cities). MONOGRAPH, garden art/landscape art, 3 [13]/2015

[16] Pawlikowska-Piechotka, A., Tradycja ogrodów działkowych w Polsce (Tradition of allotment gardens in Poland), Novae Res, 2010

[17] Works by the Commission of Cultural Landscape No 32/2016: 109-124

[18] Revitalization and development concept program for the valley of the Bystrzyca River in Lublin, INVESTPROJEKT-PARTNER 6 Sp. Z o. o. Architectural Atelier in Lublin,

[19] Schwab, Caputo, Hernandez-Garcie, 2018, Urban Agriculture: Moels-in-Circulation form Critical Transnational Perspective, Lanscape and Urban Planning, 170 p. 15-23.

[20] Schwab, E., Caputo, S., Hernandez-Garcie, J., (2018). Urban Agriculture: Models-in-Circulation from a Critical Transnational Perspective, Landscape an Urban Planning 170 (2018) 15-23. 
[21] Scott A, Dean A., Barry V., Kotter R., Landscape and Urban Planning Places of urban disorder? Exposing the hidden nature and values of an English private urban allotment landscape, Lanscape and Urban Planning, 169, 2018 p. 185-198

[22] Strojny R., Urban and architectural revitalization of degraded urban areas within the Streets: Dolna Panny Marii, Rusatka, Wesota as well as the Bystrzyca River in Lublin, 2018, engineer thesis under the direction of N. Przesmycka

[23] Szczepańska M., Krzyżaniak M., Świerk D., Urbański P., 2016, Rodzinne ogrody działkowe jako element zielonej infrastruktury na terenie aglomeracji poznańskiej (Family allotment gardens as an element of green infrastructure within the Poznań agglomeration), "Studia Miejskie” (Urban Studies) vol. 22.

[24] Szczęsny M, Kimic K., Możliwość adaptacji terenów ogrodów dziatkowych na obiekty ogólnodostępne na przykładzie ogrodu działkowego przy Kanale Gocławskim w Warszawie (Possibilities of adaptation of the areas of allotment gardens into publicly available objects on the example of the allotment garden by the Gocław Channel in Warsaw)

[25] Szkup, R. Pytel S., Rodzinne Ogrody Działkowe (ROD) w przestrzeni dużego miasta przykład Łodzi (Family Allotment Gardens (ROD) in the space of a big city on the example of the city of Łódź)

[26] Resolution number 735/XXIX/2017 as of April 27 2017 of the Council of the City of Lublin concerning the Revitalization Plan for Lublin in the years 2017-2023

[27] Act as of December $13^{\text {th }} 2013$ on family allotment gardens.

[28] Wilczyński S., Ogródki działkowe jako zagadnienia społeczne (Allotment gardens as a social question), published by the Caritas Society of Charity Associations, Poznań 1927.

[29] Województwo Lubelskie a ogrody dziatkowe (Lublin Voivodeship and allotment gardens), Association of Gardening Enthusiasts in Lublin, Lublin 1935

[30] Zakrzewski P., Nie ma jak działka, czyli narodowe hobby Polaków (There's no place like my allotment garden, i.e. on Polish national hobby), [in:] Culture.pl, April 29 2016 [access: October 14 ${ }^{\text {th }}$ 2018], <https://culture.pl/pl/artykul/nie-ma-jak-dzialka-czyli-narodowe-hobby-polakow>. 